\title{
Pembelajaran Bahasa Arab Dengan Aplikasi WhatsApp untuk Meningkatkan Kemampuan Menulis Siswa
}

\author{
Sheila Sabrina Kinanti \\ Universitas Muhammadiyah Malang \\ shelsabrin@gmail.com, \\ Anisatu Thoyyibah \\ Universitas Muhammadiyah Malang \\ anisatu thoyyibah@umm.ac.id \\ Lailatul Mauludiyah \\ Universitas Muhammadiyah Malang \\ elimauludiyah@umm.ac.id
}

\begin{abstract}
This research was conducted based on the many difficulties felt by teachers, students and guardians of students during online learning. Because many students and guardians of students were less familiar with learning technology, the researcher used WhatsApp as a learning medium. The research aimed to determine how to learn through WhatsApp. In addition, determining the level of effectiveness of WhatsApp-based online learning to improve the Arabic writing skills of 7th grade students of Generation Rabbani Bogor Junior High School. The research used quantitative method with associative types. The sample used in this research as many as 15 students from the 7th grade of Generation Rabbani Bogor Junior High School in the even semester of the 2020/2021 school year. The data was collected by observations, tests and interviews. Data analysis used included validity tests, reliability tests, paired T-tests and effectiveness tests. The results showed that the application of WhatsApp as a learning forum using group features, voice notes and cameras were proven through significant differences in pretest and posttest values. The average pretest score was 61.66
\end{abstract}


and the posttest was 83.66. As for the effectiveness test was proven based on the $\mathrm{N}$-Gain formula with a result of 57.19\%. Based on the results of research which had been done, it could be concluded that WhatsApp could improve the mahärah kitäbah of 7 th grade students of Generation Rabbani Bogor Junior High School with the category "effective".

Keywords: Writing Skills, Social Media WhatsAp

$$
\begin{aligned}
& \text { ملخص } \\
& \text { تم إجراء هذا البحث بناءً على عدد الصعوبات التي يواجهها المعلمون و الطلاب وأولياء }
\end{aligned}
$$

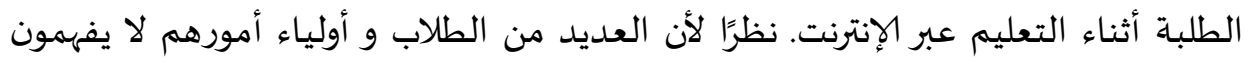

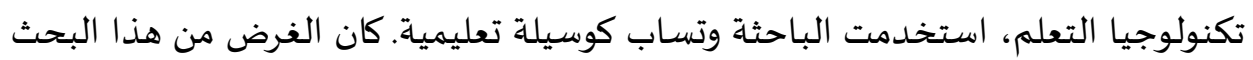

$$
\begin{aligned}
& \text { هو معرفة كيفية التعليم من خلال وتساب. بالإضافة إلى ذلك، لتحديد مدى فعالية التعليم }
\end{aligned}
$$

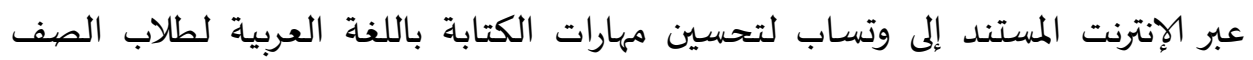

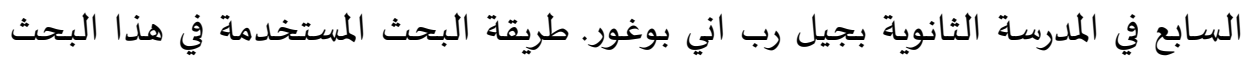

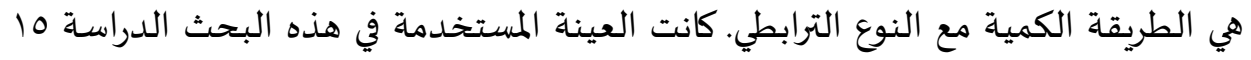

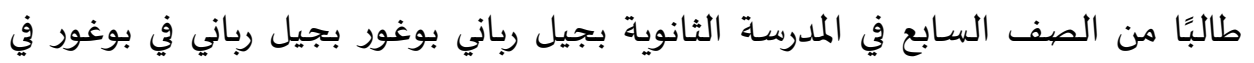

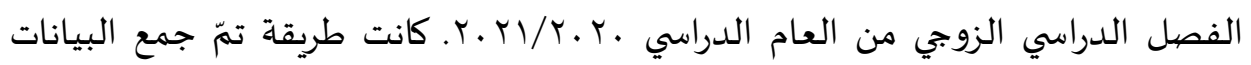

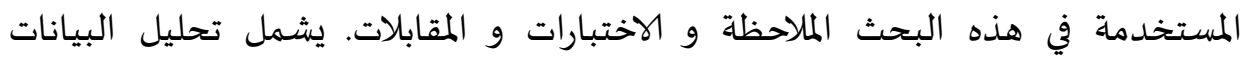

$$
\begin{aligned}
& \text { المستخدمات اختبار الصلاحية و اختبار الموثوقية و اختبار T المقترن و اختبار الفعالية. }
\end{aligned}
$$

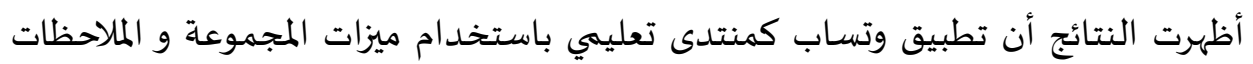

$$
\begin{aligned}
& \text { الصوتية و الكاميرات ظهر من خلال الاختلاف الكبير في درجات الاختبار القبلي و البعدي. }
\end{aligned}
$$

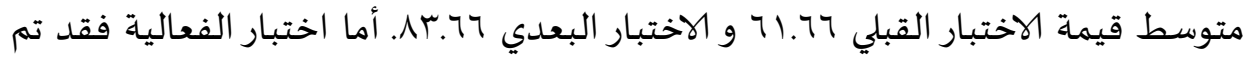

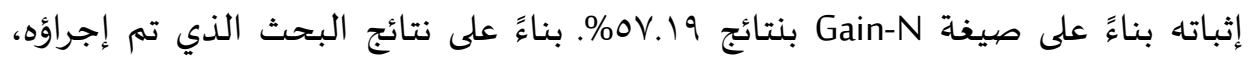

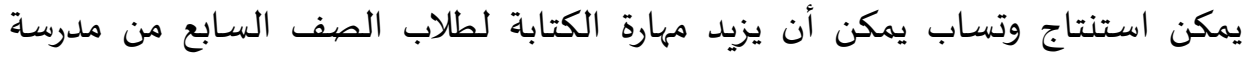

$$
\begin{aligned}
& \text { الثانوية بجيل رباني بوغور مستوى"فعال للغاية". } \\
& \text { الكلمات الأسـاسية: مهارة الكتابة، وسـائل التواصل الاجتماعي واتساب }
\end{aligned}
$$

\begin{abstract}
Abstrak
Penelitian ini dilaksanakan berdasarkan banyaknya kesulitan yang dirasakan oleh guru, siswa maupun wali siswa selama pembelajaran daring. Karena banyaknya siswa dan wali siswa kurang faham dengan teknologi pembelajaran, maka peneliti menggunakan WhatsApp sebagai media pembelajaran. Tujuan penelitian ini adalah untuk mengetahui bagaimana pembelajaran melalui WhatsApp. Selain itu juga untuk mengetahui tingkat efektivitas pembelajaran daring berbasis WhatsApp untuk meningkatkan keterampilan menulis bahasa Arab siswa kelas 7 SMP Generasi Rabbani Bogor.
\end{abstract}


Metode penelitian yang digunakan pada penelitian ini ialah kuantitatif dengan jenis asosiatif. Sampel yang digunakan pada penelitian ini sebanyak 15 siswa dari kelas 7 SMP Generasi Rabbani Bogor di semester genap tahun ajaran 2020/2021. Metode pengumpulan data yang digunakan pada penelitian ini berupa observasi, tes dan wawancara. Analisis data yang digunakan mencakup uji validitas, uji reliabilitas, uji-T berpasangan dan uji efektivitas. Hasil penelitian menunjukkan bahwa penerapan WhatsApp sebagai forum pembelajaran menggunakan fitur grup, voice note dan kamera dibuktikan melalui perbedaan signifikan nilai pretest dan posttest. Ditunjukkan rata-rata nilai pretest sebesar 61,66 dan posttest 83,66 . Sedangkan untuk uji efektivitas dibuktikan berdasarkan rumus N-Gain dengan hasil 57,19\%. Berdasarkan hasil penelitian yang telah dilakukan, dapat disimpulkan bahwa WhatsApp dapat meningkatkan mahārah kitābah siswa kelas 7 SMP Generasi Rabbani Bogor dengan kategori "cukup efektif".

Katakunci:Mahārah Kitābah, Media Sosial WhatsApp

\section{A. Pendahuluan}

Adanya kasus pertama corona virus disease 2019 (Covid-19) di Indonesia pada awal Maret 2020 lalu, membuat Indonesia dihadapkan pada masa pandemi. Banyak sektor kehidupan yang lumpuh, terutama pada bidang pendidikan. Negara berkewajiban mencarikan solusi demi keberlangsungan pendidikan agar proses pembelajaran tidak terhenti (Asmuni, 2020).

Sesuai dengan surat edaran menteri pendayagunaan aparatur negara dan reformasi birokrasi (PAN \& RB) Nomor 50/2020 tentang perubahan kedua atas surat edaran menteri PAN \& RB Nomor 19/2020 tentang penyesuaian sistem kerja aparatur sipil negara dalam upaya pencegahan penyebaran Covid-19 pemerintah menerapkan kebijakan work from home (WFH) yang berarti bekerja dari rumah.

Sesuai surat edaran tersebut, maka pemerintah memutuskan untuk meliburkan seluruh peserta didik, serta memindahkan proses belajar mengajar yang tadinya di sekolah menjadi di rumah dengan menerapkan kebijakan work from home (WFH) (Mustakim, 2020). Sebagai ASN (Aparatur Sipil Negara), guru dalam upayanya melaksanakan proses pembelajaran secara online atau dalam jaringan (daring). Namun, pelaksanaan proses pembelajaran secara online memiliki banyak sekali kendala kendala.

Secara umum, kendala dalam pembelajaran daring seperti belum 
meratanya akses jaringan internet, mahalnya biaya kuota, belum meratanya penguasaan iptek di kalangan pendidik maupun peserta didik, serta kesulitan orang tua dalam mendampingi anak-anaknya melakukan kegiatan belajar mengajar menjadi kendala yang paling banyak ditemui selama proses pembelajaran daring (Kurniawan, 2020).

Sedangkan kendala terbesar yang dihadapi selama pembelajaran daring pada SMP Generasi Rabbani Bogor yakni penguasaan iptek yang terbatas antara guru, siswa maupun wali siswa yang terbatas. Keterlibatan orang tua atau wali murid sangatlah dibutuhkan dalam proses pembelajaran daring, minimal dalam bentuk monitoring dengan cara keterlibatan, fokus, konsisten dan menguat serta memberi solusi jika anak mengalami kesulitan dalam pembelajaran. Selanjutnya orang tua juga harus serba tau tentang teknologi dalam pembelajaran agar tidak gagap teknologi (gaptek).

SMP Generasi Rabbani yang banyak dikenal oleh kalangan masyarakat Bogor yakni sebagai SMP yang unggul dalam bidang teknologi. SMP Generasi Rabbani yang beralamat di Villa Nusa Indah 3 blok KA-KB, Desa Bojong Kulur, Kecamatan Gunung Putri, Kabupaten Bogor, Provinsi Jawa Barat kode pos 16969. Lokasinya yang berada di dalam lingkungan yang mewah, membuat SMP Generasi Rabbani Bogor unggul dalam bidang teknologi.

Terlebih untuk pembelajaran daring, SMP Generasi Rabbani Bogor tentu memiliki website tersendiri. Akan tetapi seluruh tenaga pengajar di sekolah ini dibebaskan untuk memilih platform dalam pembelajarannya. Sedangkan untuk pelajaran bahasa Arab di sekolah ini menggunakan platform Google Classroom.

Pembelajaran mahārah kitābah di SMP Generasi Rabbani Bogor menggunakan media Google Classroom di mana peserta didik hanya menerima materi yang telah dibagikan oleh guru tanpa disertai dengan penjelasan via rekaman suara secara langsung pada aplikasi Google Classroom hal ini menyebabkan sebagian peserta didik kesulitan dalam memahami isi suatu materi terkait mahārah kitābah yang diberikan oleh guru. 
Pembelajaran bahasa Arab pada sekolah tersebut membuat peneliti tertarik untuk mengambil fokus pada keterampilan menulis, karena menulis merupakan salah satu keterampilan penting dalam pembelajaran bahasa Arab (Kuraedah, 2015). Keterampilan menulis (mahārahkitābah) merupakan keterampilan tertinggi di antara empat keterampilan lain dalam bahasa Arab yakni istima ' (menyimak), kalām (berbicara), qirā'ah (membaca) dan kitābah (menulis). Tidak sedikit permasalahan yang muncul dalam pembelajaran bahasa Arab berbasis daring, terutama pada keterampilan menulis.

Pembelajaran bahasa Arab yang difokuskan pada keterampilan menulis ini tentunya banyak sekali permasalahan, salah satu permasalahan yang terlihat jelas justru ada pada salah satu keunggulan yang dimiliki oleh sekolah ini yang membuat banyak siswa dan wali siswa kesulitan. Keunggulan tersebut ialah teknologi pembelajaran yang semakin canggih, sedangkan pengetahuan iptek yang dimiliki oleh siswa kurang. Menurut (Daheri et al., 2020) Berbagai macam platform aplikasi belajar daring yang canggih justru dapat menyulitkan bagi siswa, sedangkan guru menuntut siswa nya memahami platform tersebut.

Sedangkan keterbatasan pengetahuan iptek ini, mempunyai imbas yang besar terhadap siswa, salah satunya banyak siswa yang tidak mengikuti pembelajaran dengan baik serta tidak mengetahui cara untuk mengumpulkan tugas menggunakan Google Classroom, bahkan hingga tidak mengikuti ujian. Hal inilah yang dapat menurunkan prestasi belajar siswa pada pembelajaran bahasa Arab.

Karena banyak keluhan dari siswa ketika belajar melalui google classroom, salah satunya yaknipada aplikasi google classroom, tidak ada fitur penjelasan langsung berupa suara. Sedangkan pembelajaran melalui media sosial WhatsApp siswa dapat dengan mudah memahami materi pembelajaran mahārah kitābah. Hal tersebut terjadi karena didukung oleh fitur WhatsApp berupa voice note, dimana pendidik dapat mengirimkan penjelasan langsung berupa pesan suara yang dapat disengar oleh peserta didik.

Banyak sekali kelebihan yang didapat guru pada aplikasi Google 
classroom untuk memaksimalkan pembelajaran daring. Beberapa di antaranya siswa bisa langsung mengikuti proses belajar dari rumah, siswa tidak bergantung pada guru, serta siswa dilatih untuk lebih menguasai teknologi informasi yang terus berkembang. Akan tetapi dibalik semua kelebihan tersebut banyak juga kekurangan yang dihadapi. Di antaranya tidak semua siswa memiliki dan mampu mengakses peralatan yang dibutuhkan (baik itu komputer, laptop, atau gawai lainnya) untuk pembelajaran online dan pada akhirnya tidak dapat mengupgrade pengetahuan teknologi yang berakibat gaptek (Apriliana, 2015).

Berdasarkan permasalahan tersebut, peneliti menggunakan aplikasi WhatsApp sebagai sarana pembelajaran daring pada mata pelajaran bahasa Arab di SMP Generasi Rabbani Bogor. Aplikasi ini mempunyai kelebihan yakni relatif murah dalam pemakaian kuota internet selain itu, hampir semua orang tua, peserta didik dan pendidik sudah mengenalnya dan mudah dalam penggunaannya. Harapannya tidak mempersulit untuk orang tua dan peserta didik dalam penggunaan media tersebut agar proses belajar tetap berjalan. dengan menggunakan media pembelajaran yang mudah di akses dan umum di kalangan masyarakat, yakni aplikasi WhatsApp.

Sedangkan, jika pembelajaran menggunakan platform yang mudah, maka siswa tidak akan kesulitan untuk mengumpulkan tugasnya. Penelitian ini menggunakan media sosial WhasApp, karena jika hanya komunikasi texting melalui WhatsApp Grup maka tidak akan menyulitkan siswa, karena WhatsApp familiar digunakan di kalangan masyarakat. Maka dari itu, selama pandemi Covid-19WhatsApp banyak digunakan sebagai sarana komunikasi antara guru, siswa dan wali siswa (Daheri et al., 2020).

Pembelajaran melalui WhatsApp (WA) merupakan aplikasi favorit (Iskandar, 2020). Sebab WA sudah sangat banyak penggunaannya di kalangan masyarakat. WhatsApp menyajikan beberapa fitur yang menarik serta mudah dalam pengoperasiannya. Fitur tersebut meliputi penyampaian pesan perorangan, penyampaian pesan dalam grup, melampirkan video, 
melampirkan foto, melampirkan file dalam bentuk PDF ataupun word, panggilan suara dan video. Serta mengirimkan pesan suara dan WA relatif lebih terjangkau jika dibandingkan dengan aplikasi yang lain.

Menurut penelitian yang dilakukan oleh (Larasati, 2013) pemanfaatan aplikasi WhatsApp sebagai sarana dari pembelajaran daring ini dinilai sangat efektif. Ditinjau dari keseluruhan fitur yang dimiliki oleh aplikasi WhatsApp lebih mendukung dibandingkan aplikasi lainnya. Berbagai macam fitur yang dimiliki oleh WhatsApp tersebut yang menambah kemudahan dan kenyamanan berkomunikasi melalui media online(Jumiatmoko, 2016). Sedangkan menurut (Daheri et al., 2020) Penggunaan WhatsApp sebagai media belajar daring ini justru dinilai kurang efektif.

Berdasarkan penelitian yang telah dilakukan oleh peneliti sebelumnya, terlihat bahwa efektivitas pembelajaran menggunakan WhatsApp mendapatkan hasil yang berbeda. Oleh karena itu, diperlukan adanya penelitian lebih lanjut terkait efektivitas pembelajaran daring menggunakan WhatsApp. Selain untuk melihat bagaimana efektivitas belajar daring melalui WhatsApp pada mahārah kitābah peneliti juga akan membahas bagaimana sistem belajar melalui media sosial serta respon siswa selama pembelajaran menggunakan WhatsApp.

Tujuan penelitian ini yang pertama, untuk mengetahui penerapan media sosial WhatsApp pada mata pelajaran bahasa Arab dengan tingkat kemampuan menulis mahārah kitābah siswa di kelas 7 SMP Generasi Rabbani Bogor pada semester genap tahun ajaran 2020/2021. Dan yang kedua, untuk mengetahui efektivitas pembelajaran daring menggunakan media sosial WhatsApp untuk meningkatkan mahārah kitābah pada siswa kelas 7 SMP Generasi Rabbani Bogor pada semester genap tahun ajaran 2020/2021. Dengan adanya penelitian ini, diharapkan keterampilan menulis bahasa Arab siswa meningkat dan WhatsApp dapat efektif digunakan dalam pembelajaran.

\section{B. Pembahasan dan Hasil}

\section{Kajian Teori}

\section{a. Media Pembelajaran Berbasis WhatsApp}


Menurut Pranajaya dan Hendra Wicaksono, WhatsApp merupakan media sosial terpopuler yang digunakan sebagai media untuk berkomunikasi. Sedangkan WhatsApp ini salah satu aplikasi yang mempunyai kelebihan, di mana pesan yang ditulis tidak mempunyai batasan huruf sehingga pengirim pesan merasa puas dengan sarana aplikasi WhatsApp (Nurhayati, 2019).

WhatsApp sebagai salah satu media sosial saat ini banyak yang menggunakan untuk kepentingan bersosialisasi maupun sebagai penyampaian pesan baik oleh individu maupun kelompok (Trisnani, 2017). Pemanfaatan program WhatsApp sangat efektif dengan dukungan fitur-fitur nya dibanding dengan aplikasi pesan instan lainnya (Larasati, 2013).

Berbagai fitur tersebut tentu semakin menambah kemudahan dan kenyamanan berkomunikasi melalui media online (Jumiatmoko, 2016). Selain itu Juga, WhatsApp menyediakan Fitur-fitur yaitu galeri untuk menambahkan foto, kontak untuk menyisipkan kontak, kamera untuk mengambil gambar, Audio untuk mengirim pesan suara, maps untuk mengirimkan berbagai koordinat peta, bahkan dokumen untuk menyisipkan file berupa dokumen. Semua file tersebut dapat dalam sekejap dikirim melaui aplikasi gratis tersebut.

Adapun jenis fitur WhatsApp yang digunakan dalam penelitian ini menurut (Prajana, 2017) antara lain: 1)Chat Group, Fitur ini digunakan untuk menyatukan antara pengajar dan pelajar dalam satu forum di mana mereka dapat berdiskusi dengan bentuk teks yang dapat dilihat oleh seluruh peserta grup tersebut. 2)Fasilitas Share Dokumen, Fitur ini digunakan untuk membantu pengajar mengirim dokumen dalam bentuk file. 3)Kamera, Pada penelitian ini, fitur kamera digunakan untuk memfoto dan mengumpulkan hasil tugas yang telah dikerjakan oleh siswa. 4)Galeri, Fitur ini digunakan untuk membagi atau mengirimkan gambar/video yang telah tersimpan sebelumnya. 5)Audio, Fitur ini dapat digunakan untuk membagikan file berbentuk suara. 6)YouTube Video Box, 
Yakni aplikasi yang dapat digunakan untuk berbagi koleksi video di WhatsApp.

Seluruh siswa di Indonesia pada era digital ini telah menggunakan WhatsApp dalam aktivitasnya sehari-hari mereka baik itu untuk kebutuhan sekolah maupun kebutuhan di luar sekolah. Akan tetapi, sebagian besar siswa di Indonesia menggunakan aplikasi WhatsApp, hanya untuk bermedia sosial saja, padahal di dalam aplikasi tersebut terdapat banyak sekali manfaat yang dapat meningkatkan kemampuan literasi digital terutama dalam bidang pendidikan (Iskandar, 2020).

Melalui aplikasi WhatsApp sebagai forum penyebaran materi, pembelajaran dapat dilaksanakan dengan baik salah satu caranya adalah dengan membentuk WhatsApp grup, di dalam WhatsApp grup tersebut akan secara otomatis diketahui jika ada yang mengirimkan pesan tertentu dan yang lainnya bisa dengan memberikan tanggapan yang jelas terkait topik yang ingin didiskusikan.

Berbagi materi pelajaran (menggunakan fitur WhatsApp grup) dapat menyatukan antara pengajar dan pelajar dalam satu forum di mana mereka dapat berdiskusi dengan bentuk teks yang dapat dilihat oleh seluruh peserta grup tersebut. Adapun kegiatan yang dilakukan dalam penyampaian materi pembelajaran adalah sebagai berikut:1)Guru membagikan pengumuman dalam grup WA berupa akses untuk absen, akses materi serta tata cara pengerjaan dan pengumpulan tugas. 2)Materi pembelajaran secara keseluruhan disajikan dalam bentuk video pembelajaran yang dapat di akses melalui link YouTube. Agar materi bahasa Arab dapat tersampaikan dengan baik, diwajibkan bagi semua peserta didik untuk menyimak video pembelajaran tersebut. 3)Penyajian materi pembelajaran disampaikan dalam bentuk video yang mudah difahami dan dilengkapi dengan terjemahan bahasa Indonesia sesuai dengan materi yang sudah dirancang dalam RPP. 4)Kemudian siswa diminta unruk mengerjakan tugas yang ada di pertengahan/akhir video.

Evaluasi pembelajaran dalam penelitian ini dilaksanakan setelah 
kegiatan pembelajaran selesai, dilakukan untuk melihat sejauh mana perkembangan pengetahuan peserta didik setelah melewati proses pembelajaran. Pembelajaran berbasis WhatsApp ini perlu dilakukan evaluasi untuk mengukur sejauh mana pemahaman peserta didik dalam memahami materi dan untuk mengetahui kesulitan-kesulitan yang dialami selama pembelajaran. Kegiatan evaluasi dilakukan sebagai berikut: 1)Evaluasi materi diberikan dalam bentuk tugas, yang berada di akhir/ pertengahan video. Hal ini dilakukan agar siswa dapat menyimak dengan baik keseluruhan video yang telah diberikan. 2)Pengumpulan tugas sebagai bahan evaluasi dilakukan dengan menuliskan tugasnya di buku masing-masing, difoto dan dikirimkan melalui chat pribadi. Hal ini dilakukan untuk melihat sejauh mana pemahaman peserta didik mengenai materi pembelajaran pada pertemuan itu. 3)Kemudian selain pemberian tugas mingguan untuk melihat perkembangan peserta didik, evaluasi juga diadakan pada setiap akhir materi.

Setiap model pembelajaran pasti memiliki kelebihan dan kekurangan masing-masing demikian pula dengan pembelajaran dengan menggunakan media WhatsApp, memiliki beberapa kelebihan, di antaranya: 1)Pembelajaran dapat dilakukan di mana saja dan kapan saja. Dengan melakukan pembelajaran online jangkauan pembelajaran menjadi tidak terbatas pada ruang kelas, melainkan seluruh penjuru dunia. 2)Pembelajaran menjadi lebih praktis, dan menarik. Dengan melihat ketertarikan masyarakat kepada WhatsApp yang sangat tinggi dan dengan model pembelajaran yang sudah dikemas dengan sistematis, maka pembelajaran menjadi lebih praktis dan menarik. 3) Kegiatan diskusi memiliki waktu yang banyak. Selama ini dalam sistem pembelajaran kegiatan diskusi selalu terbatasi oleh waktu, baik itu waktu di ruang pembelajaran maupun waktu di forum diskusi lainnya, tapi dengan pembelajaran media WhatsApp kegiatan diskusi bisa dilakukan kapanpun tanpa terhalang waktu. 
Selain memiliki banyak kelebihan, pembelajaran berbasis online menggunakan WhatsApp juga memiliki beberapa kekurangan di antaranya: 1)Tertumpu kepada data internet, karena pembelajaran ini berbasis internet maka akan ada keharusan bagi peserta untuk memiliki data internet. Sehingga bagi peserta yang tidak memiliki data internet maka tidak akan bias mengikuti kegiatan pembelajaran. 2) Pengukuran kemampuan kognitif peserta didik kurang, Karena kegiatan pembelajaran hanya dilakukan melalui WhatsApp saja dan tidak ada pertemuan tatap muka antara narasumber dan peserta didik, maka kemampuan kognitif peserta didik hanya dapat diukur dari jawaban latihan soal yang dikirim peserta didik saja tanpa tau bagaimana cara peserta didik menjawab soal latihan. 3)Pengontrolan peserta didik kurang. Peserta didik berada di berbagai lokasi dengan jarak yang jauh, dengan demikian pengontrolan peserta didik akan terasa lebih sulit.

\section{b. Mahārah Kitābah}

Sebagaimana yang telah kita ketahui, mahārah kitābah atau yang biasa dikenal juga dengan keterampilan menulis merupakan salah satu dari empat mahārah yang harus dikuasai dalam mempelajari bahasa, baik itu bahasa Indonesia, Inggris maupun Arab. Keterampilan sendiri menurut kamus besar bahasa Indonesia (KBBI) adalah kecakapan untuk menyelesaikan tugas.

Mahārah dalam bahasa Arab berasal dari kata dasar مهر berubah menjadi bentuk masdar مهارة yang berarti kemahiran atau keterampilan sedangkan kata كتابة yang berarti menulis atau tulisan adalah bentuk masdar yang berasal dari kata كتب (kataba) yang berarti menulis (Kuraedah, 2015).

Menulis merupakan komunikasi yang dilaksanakan tanpa didukung oleh tekanan suara, nada, dan lainnya. Dengan demikian, penulis harus pandai memanfaatkan kata-kata, ungkapan, kalimat, serta menggunakan 
symbol untuk menyampaikan, menginformasikan, melukiskan dan menyarankan sesuatu kepada orang lain (Fahrurrozi, 2014).

Beberapa pengertian yang telah dikemukakan oleh beberapa ahli di atas, maka dapat disimpulkan bahwa keterampilan menulis sebagai keterampilan yang menggambarkan atau melukiskan tanda-tanda atau simbol-simbol huruf dengan ketentuan yang telah ditetapkan. Ranah keterampilan menulis dalam pembelajaran bahasa Arab menjadi hal yang terpenting untuk dilakukan. Penguasaan yang tepat pada aktivitas menulis, akan menghindari pembelajar pada kesalahan-kesalahan dalam bahasa tulis (Hamid, 2013).

\section{c. Tahapan Pembelajaran Mahārah Kitābah}

Agar diperolehnya hasil yang efektif dari pembelajaran keterampilan menulis, maka perlu di ketahui bahwasanya aktivitas menulis terbagi menjadi beberapa tahapan menurut Dr. Abdul Munim Sayyid Abdul 'Al terdapat 3 macam, yaitu: 1) Imlä' Manqūl (disalin), Disebut juga dengan imlā' menyalin yakni dengan menyalin tulisan yang telah ditulis oleh guru yang dilanjutkan oleh peserta didik dengan meniru dengan menulis pada buku tulis. Latihan menulis seperti ini cocok untuk diberikan kepada pemula. 2) Imlā' Mandzūr (dilhat), Atau imlā' mengamati yaitu imlā' dengan cara mengamati yaitu tulisan yang tertera pada media tertentu dilihat lalu dihapus kemudian peserta didik disuruh menulis kembali ke dalam buku tanpa melihat tulisan. Imlä' ini juga lazim disebut imlä' mansukh, sebab dilakukan dengan cara menyalin tulisan yang telah dihapus setelah diperlihatkan tulisannya kepada peserta didik. Jenis $i m l \bar{a}^{\prime}$ ini merupakan lanjutan dari imlä' yang disalin dan tingkat kesulitannya lebih tinggi dibandingkan dengan imlā' manqūl. Imlä' ini diajarkan setelah siswa mahir dalam imlā'yang disalin (Kuraedah, 2015). 3) Imlā' Ikhtibāriy/Masmū' (didengar), Disebut juga dengan Imlā' menyimak yakni dengan cara guru memperdengarkan kepada siswa beberapa potongan kata atau kalimat. Ketika guru membacakan kata/kalimat dalam bahasa Arab peserta didik 
langsung menulisnya. Jenis imlä' ini merupakan $i m l \bar{a}^{\prime}$ lanjutan dari $i m l \bar{a}^{\prime}$ yang mandzur. Imlä' ini Diajarkan setelah peserta didik mahir dalam $i m l \bar{a}^{\prime}$ mandzūr. Imlā' ini tingkatannya lebih sukar dari $i m l \bar{a}^{\prime}$ yang lainnya.

Sedangkan menurut Syaiful Mustopa, mengemukakan bahwa dalam mahārah kitābah, proses pembelajaran dilakukan dengan beberapa tingkataan yang dimulai dari pelajaran imlä' hingga ta'bir. Berikut pembelajaran imlā' menurut Syaiful Mustofa : (1) Imlä' Manqūl (disalin), Digunakan untuk memperbaiki kemampuan peserta didik dalam menulis huruf dan kata bahasa Arab, dengan membaca teks Arab kemudian menulis ulang tanpa melihat kembali pada buku. Kemudian membandingkan dengan tulisan sebenarnya untuk mengecek kembali dari sisi kebenaran tulisannya. (2) Imlā' Manżūr (dilihat), Memperbaiki kemampuan peserta didik dalam menulis huruf dan kata bahasa Arab, dengan cara siswa diminta untuk menulisnya sebagian kalimat yang sudah dipelajari dan diperbolehkan melihat teks sekiranya dibutuhkan. (3) Imlä' Ikhtibary (ujian/testing), Pelaksanaannya membutuhkan tiga kemampuan, yakni kemampuan mendengar, kemampuan menghafal, dan kemampuan untuk menuliskan apa yang didengar sekaligus dalam waktu yang sama.

Sedangkan untuk model pembelajaran ta'bir tahapan pelaksanaannya adalah: (1) Ta'bir Muwajjah (terbimbing), Peserta didik diberi kebebasan untuk memilih kata-kata/tarkib. Pembelajaran tingkat ini harus bertahap mulai dari menulis satu kalimat sederhana kemudian berkembang menjadi beberapa kalimat, setelah itu berlanjut menjadi satu paragraf kemudian dua paragraf dan seterusnya. (2) Ta'bir Hurr (menulis bebas), Pembelajaran dimulai dengan pemilihan tema yang sesuai dengan tingkat kebahasaan peserta didik dari sisi kosakata, tarkib, dan penggunaan kaidah-kaidah bahasa, kemudian diperluas dengan pengalaman atau pikiran-pikiran yang bisa membawa pikiran peserta didik pada hal-hal yang berhubungan dengan teks.

\section{d. Tujuan Pembelajaran Mahārah Kitābah}

Menurut Iskhandar Wassit dalam bukunya yang berjudul "strategi 
pembelajaran bahasa" menjelaskan bahwa tujuan dari pembelajaran keterampilan menulis berdasarkan tingkatan, di antaranya: 1) Tingkat Pemula, a) Menyalin satuan-satuan bahasa yang sederhana, b) Menulis satuan bahasa yang sederhana, c) Menulis pernyataan dan pertanyaan yang sederhana, d) Menulis paragraf pendek. 2) Tingkat Menengah, a) Menulis pernyataan dan pertanyaan, b) Menulis paragraf, c) Menulis surat, d)Menulis karangan pendek, e) Menulis laporan.

Adapun tujuan dari pembelajaran mahārah kitābah menurut Izzan (2011) dalam bukunya yang berjudul "Metodologi Pembelajaran Bahasa Arab" adalah sebagai berikut: 1) Agar siswa mampu menuliskan kata-kata dan kalimat bahasa Arab dengan mahir dan benar. 2) Agar siswa mampu menuliskan dan membaca kata-kata dalam kalimat bahasa Arab secara terpadu. 3) Melatih panca indra siswa untuk menjadi aktif berbahasa Arab. Baik melalui perhatian, pendengaran, penglihatan, pengucapan maupun penulisan. 4) Menumbuhkan penulisan bahasa Arab yang indah dan rapi. 5) Menguji kembali pengetahuan siswa tentang penulisan kalimat yang telah dipelajari. 6) Melatih siswa mengarang dengan bahasa Arab dengan menggunakan gaya bahasanya sendiri.

Penelitian ini terfokus pada tujuan pembelajaran mahārah kitābah di tingkat pemula dengan target siswa mampu menuliskan dan membaca kata-kata dalam kalimat bahasa Arab secara terpadu serta menguji kembali pengetahuan siswa tentang penulisan kalimat yang telah dipelajari.

\section{Metode Penelitian}

Pendekatan yang digunakan dalam penelitian ini adalah kuantitatif. Menurut Sugiyono (2017) penelitian ini disebut kuantitatif karena data penelitian berupa angka-angka dan analisis menggunakan statistik. Sedangkan jenis penelitian yang dilakukan dalam penelitian ini adalah penelitian asosiatif. Menurut (Sugiyono, 2017) penelitian asosiatif adalah penelitian yang bertujuan untuk mengetahui hubungan antara dua variabel atau lebih. 
Teknik sampling dalam penelitian ini menggunakan purposivesampling. Purposive sampling yakni teknik pengambilan sampel dengan menentukan kriteria-kriteria tertentu (Sugiyono, 2011). Pemilihan subjek dalam purposive sampling disesuaikan dengan kriteria tertentu yang diterapkan berdasarkan tujuan penelitian. Sedangkan populasi yang digunakan dalam penelitian ini adalah siswa SMP Generasi Rabbani Bogor yang jumlahnya 60 siswa. Peneliti memilih sebanyak 15 siswa dari kelas 7 SMP Generasi Rabbani Bogor untuk dijadikan sampel.

Metode pengumpulan data pada penelitian ini menggunakan observasi, tes dan wawancara. Tujuan adanya observasi pada penelitian ini untuk mendapatkan informasi tentang materi pembelajaran, metode pembelajaran dan platform yang digunakan sebelumnya. Sedangkan tes pada penelitian ini berbentuk tes tertulis (pretest \& posttest) tujuannya agar mengetahui peningkatan kemampuan siswa. Yang terakhir yakni wawancara, Teknik wawancara dalam penelitian ini berupa wawancara tidak terstruktur dan bersifat informal. yang akan dijadikan responden untuk diwawancarai adalah guru mata pelajaran bahasa Arab SMP Generasi Rabbani Bogor serta wali murid kelas 7 SMP Generasi Rabbani Bogor.

Analisis data pada penelitian ini menggunakan uji-T berpasangan dan uji efektivitas. Uji T sampel digunakan untuk mengetahui apakah terdapat peningkatan kemampuan keterampilan menulis bahasa Arab siswa setelah menggunakan WhatsApp sebagai sarana belajar menggunakan rumus uji-T berpasangan. Sedangkan untuk tingkat efektivitas dapat dihitung dengan menghitung skor Gain yang dinormalisasi dengan rumus N-Gain. Untuk kategori tafsiran efektivitas dari Gain menurut (Arini, 2016) yaitu:

\begin{tabular}{cc}
\hline$<76 \%$ & Efektif \\
\hline $56 \%-75 \%$ & Cukup Efektif \\
\hline $40 \%-55 \%$ & Kurang Efektif \\
\hline$>40 \%$ & Tidak Efektif
\end{tabular}

Tabel 1 Kategori Tafsiran Efektivitas dari Gain 


\section{Hasil}

Berdasarkan pembahasan tersebut, dapat direncanakan skenario dari pelaksanaan tahapan pembelajaran mahārah kitābah untuk siswa SMP Generasi Rabbani Bogor:

\begin{tabular}{|c|c|c|c|}
\hline $\begin{array}{c}\text { Alokasi } \\
\text { Waktu }\end{array}$ & Kegiatan & Guru & Siswa \\
\hline 5 menit & Pembuka & $\begin{array}{l}\text { - Salam, sapa, do'a \& } \\
\text { motivasi }\end{array}$ & - Menjawab salam \& doa \\
\hline $\begin{array}{l}20 \\
\text { menit }\end{array}$ & Isi & 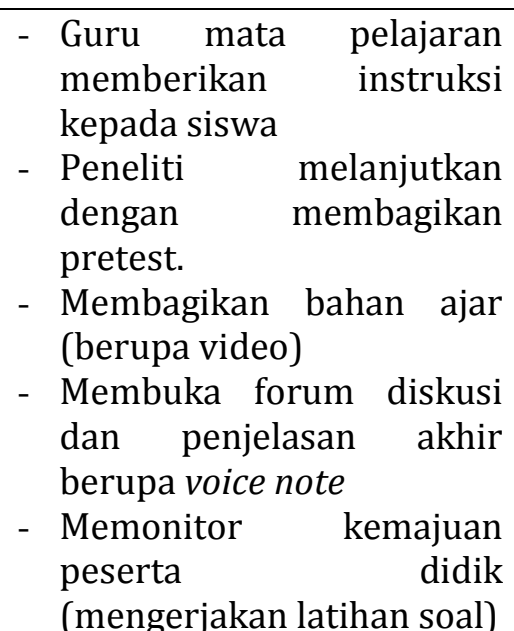 & $\begin{array}{ll}\text { - } & \text { Mengerjakan pretest di } \\
\text { buku catatan masing- } \\
\text { masing } \\
\text { - } \text { Menyimak materi } \\
\text { pembelajaran di } \\
\text { dampingi oleh wali } \\
\text { murid } \\
\text { - } \text { Bertanya jika masih } \\
\text { ada pembahasan yang } \\
\text { kurang jelas) } \\
\text { - } \\
\text { Mengerjakan posttest }\end{array}$ \\
\hline 5 menit & Penutup & $\begin{array}{l}\text { - Menginformasikan } \\
\text { ketentuan pengumpulan } \\
\text { pretest } \\
\text { - Do'a \& penutup }\end{array}$ & $\begin{array}{l}\text { - Merespon doa \& salam } \\
\text { penutup } \\
\text { - Mengumpulkan posttest } \\
\text { \& pretest dengan } \\
\text { mengambil gambar dan } \\
\text { dikirim melalui chat } \\
\text { pribadi. }\end{array}$ \\
\hline
\end{tabular}

\section{Tabel 2 Skenario Pembelajaran Pertemuan Pertama}

Berdasarkan tabel 2 pada pertemuan pertama diawali dengan guru mapel yang memberikan instruksi kepada kelas 7 agar mempermudah proses pembelajaran. Dilanjutkan dengan membagikan pretest oleh peneliti sebelum memulai pembelajaran. Kemudian memulai pembelajaran dengan membagikan video pembelajaran. Di sini siswa diminta untuk menyimak materi pada video tersebut. Setelah itu guru membuka forum diskusi dengan fitur voice note. Diakhiri dengan latihan soal, pengarahan tentang pengumpulan pretest, dan do'a penutup. Pada pertemuan selanjutnya, 
menggunakan skenario pembelajaran yang kedua sebagai berikut:

\begin{tabular}{|c|c|c|c|}
\hline $\begin{array}{l}\text { Alokasi } \\
\text { Waktu }\end{array}$ & $\begin{array}{c}\text { Kegiatan } \\
\text { pembelajaran }\end{array}$ & Guru & Siswa \\
\hline 5 menit & Pembuka & $\begin{array}{l}\text { - Salam, sapa do ‘a } \\
\text { - Motivasi }\end{array}$ & $\begin{array}{l}\text { - Merespon salam \& } \\
\text { do' a }\end{array}$ \\
\hline 20 menit & Isi & 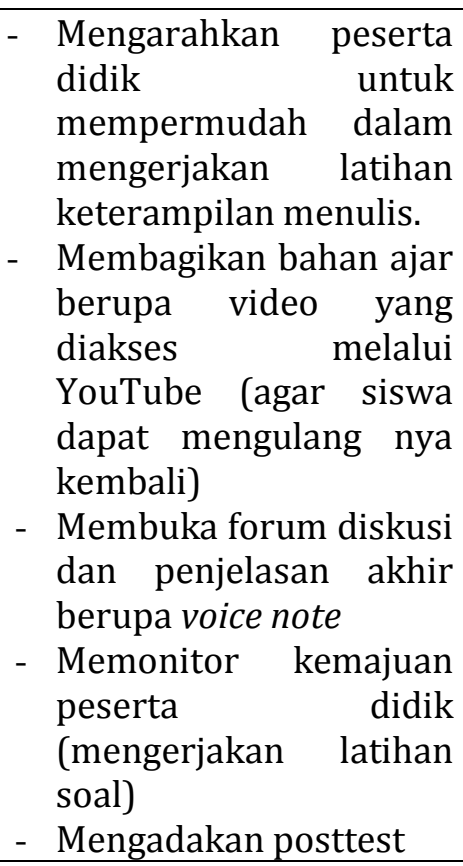 & $\begin{array}{l}\text { - Mendengarkan } \\
\text { arahan dari } \\
\text { peneliti } \\
\text { - Menyimak materi } \\
\text { pembelajaran } \\
\text { (didampingi oleh } \\
\text { wali murid) } \\
\text { - Bertanya saat } \\
\text { forum diskusi } \\
\text { dibuka } \\
\text { - Mengerjakan } \\
\text { posttest }\end{array}$ \\
\hline 5 menit & Penutup & $\begin{array}{l}\text { - Menginformasikan } \\
\text { ketentuan pengumpulan } \\
\text { posttest } \\
\text { - Do'a \& penutup }\end{array}$ & 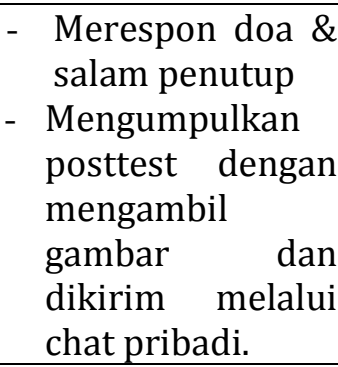 \\
\hline
\end{tabular}

Tabel 1 Skenario Pembelajaran Pertemuan Kedua

Berdasarkan tabel 3 pada pertemuan kedua, seperti biasanya guru membagikan bahan ajar berupa video pembelajaran. Kemudian siswa diminta untuk mempelajari materi dari video yang telah dibagikan tersebut. Guru memonitor proses perkembangan siswa melaui latihan soal yang diberikan pada akhir pembelajaran (posttest). Selain itu, guru juga membuka forum diskusi dalam grup melalui fitur voice note.

Berdasarkan hasil observasi di SMP Generasi Rabbani Bogor peneliti mendapatkan informasi mencakup pembelajaran bahasa Arab di kelas 7 SMP Generasi Rabbani Bogor. Beberapa di antaranya ialah metode pembelajaran, 
materi pelajaran dan platform yang digunakan sebelum WhatsApp. Metode yang digunakan oleh guru mata pelajaran bahasa Arab ialah fahmul masmu',pada metode ini lebih ditekankan pada kegiatan mendengarkan atau istima'.Materi pembelajaran yang sedang ditempuh saat peneliti terjun untuk penelitian di kelas 7 SMP Generasi Rabbani Bogor ialah materi di bab 5 pada buku pelajaran penerbit Erlangga. Sedangkan platform yang digunakan untuk belajar ialah zoom meeting\& google classroom.

Hasil tes yang terdapat pada penelitian ini disebut dengan latihan soal. Peneliti menggunakan soal pretest dan posttest untuk memperoleh hasil dalam evaluasi pembelajaran.

\begin{tabular}{ccccccc}
\hline Soal & N & Mean & Median & $\begin{array}{c}\text { Nilai } \\
\text { Minimum }\end{array}$ & $\begin{array}{c}\text { Nilai } \\
\text { Maksimum }\end{array}$ & $\begin{array}{c}\text { Jarak } \\
\text { nilai }\end{array}$ \\
\hline Pretest & 15 & 61,66 & 60 & 40 & 100 & 60 \\
\hline Posttest 1 & 15 & 83,33 & 95 & 40 & 100 & 60 \\
\hline Posttest 2 & 15 & 93,33 & 100 & 60 & 100 & 40 \\
\hline
\end{tabular}

Tabel 4 Analisis Data Nilai Pretest dan Posttest

Tabel 4 menjelaskan bahwa nilai akhir rata-rata dari hasil belajar siswa setelah menggunakan media sosial WhatsApp untuk meningkatkan keterampilan menulis bahasa Arab adalah 93,33 yang mana dapat disimpulkan bahwa hasil belajar siswa sudah baik.

Peneliti melakukan wawancara dengan guru mata pelajaran bahasa Arab dan seluruh wali murid kelas 7 SMP Generasi Rabbani Bogor. Pertanyaan yang digunakan yakni mengenai proses pembelajaran selama daring, problematika dalam belajar bahasa Arab selama online dan kemampuan menulis siswa dalam pelajaran bahasa Arab yang diajukan secara bebas kepada subjek. Narasumber yang pertama yakni guru mata pelajaran bahasa Arab, mengungkapkan bahwa:

"Menurut saya, siswa masih banyak yang kurang minat dengan pelajaran bahasa Arab, terutama pada mahārah kitābah. Karena tidak semua siswa kelas 7 di sini berasal dari lulusan SD swasta atau MI, sehingga masih banyak yang belum mengenal huruf hija'iyah", (Hasil wawancara lisan dengan guru bahasa Arab). 
Berdasarkan pernyataan tersebut, peneliti menguraikan bahwasanya minat siswa dalam belajar bahasa Arab di kelas 7 SMP Generasi Rabbani Bogor masih tergolong kurang. Sedangkan terkait platform pembelajaran, narasumber menyatakan:

"Selama pembelajaran daring ini, saya menggunakan google classroom dan zoom meeting. Platform zoom meeting saya gunakan untuk menyampaikan materi dan berdiskusi, sedangkan platform google classroom saya gunakan hanya untuk mengumpulkan tugas aja. Masih ada beberapa siswa yang tidak mengikuti pembelajaran dari berbagai macam alasan, mulai dari asalan HP yang masih belum memadai untuk mengikuti pembelajaran, tidak faham cara menggunakan google classroom hingga HP yang masih harus bergantian dengan adik/kakak", (Hasil wawancara lisan dengan guru bahasa Arab).

Pernyataan tersebut menguraikan bahwa pengetahuan teknologi yang kurang dan fasilitas yang belum memadai untuk menggunakan media belajar yang tergolong berat di handphone yang menghambat siswa untuk mengikuti pelajaran bahasa Arab. Sedangkan untuk hasil wawancara dengan wali murid sebagai pendamping siswa ketika belajar menggunakan WhatsApp pada mata pelajaran bahasa Arab, didapati bahwa:

"Sebelum menggunakan WhatsApp, anak-anak belajar bahasa Arab menggunakan zoom meeting dan google classroom. Terkadang cukup sulit untuk Handphone dengan kapasitas memori terbatas, selain itu juga butuh waktu untuk mempelajari aplikasi tersebut", (Hasil wawancara tertulis dengan wali murid).

Pernyataan tersebut menjelaskan bahwa aplikasi zoom dan google classroom membuat beberapa siswa dan wali siswa sulit untuk mengakses nya. Sedangkan untuk wawancara bersama wali murid terkait efektivitas pembelajaran menggunakan WhatsApp didapati bahwa:

"Pembelajaran menggunakan WhatsApp melihat belakangan ini saya rasa cukup efektif dibandingkan dengan aplikasi lain, meski tentu ada kekurangannya", (Hasil wawancara dengan wali murid).

Berdasarkan hasil wawancara kepada guru mata pelajaran bahasa Arab dan wali murid kelas 7 SMP Generasi Rabbani Bogor yang telah dilakukan oleh peneliti dapat disimpulkan bahwa: 
1. Kurangnya minat siswa dalam pembelajaran bahasa Arab.

2. Platform yang berat dan sulit dijangkau bagi sebagian siswa.

3. Kurangnya pemahaman siswa dan wali siswa tentang teknologi pembelajaran.

Berikut hasil perhitungan uji T sampel menggunakan SPSS 25.

Tabel 5 Hasil Uji Sampel Berpasangan

\begin{tabular}{|c|c|c|c|c|c|c|c|c|}
\hline \multicolumn{9}{|c|}{ Paired Samples Test } \\
\hline & \multicolumn{5}{|c|}{ Paired Differences } & \multirow{3}{*}{$\mathrm{T}$} & \multirow{3}{*}{$\mathrm{df}$} & \multirow{3}{*}{$\begin{array}{l}\text { Sig. (2- } \\
\text { tailed) }\end{array}$} \\
\hline & \multirow{2}{*}{ Mean } & \multirow{2}{*}{$\begin{array}{c}\text { Std. } \\
\text { Deviation }\end{array}$} & \multirow{2}{*}{$\begin{array}{l}\text { Std. } \\
\text { Error } \\
\text { Mean }\end{array}$} & \multicolumn{2}{|c|}{$\begin{array}{l}\text { 95\% Confidence Interval of the } \\
\text { Difference }\end{array}$} & & & \\
\hline & & & & Lower & Upper & & & \\
\hline Pair 1 & $\begin{array}{l}\text { Pretest- } \\
\text { Posttest }\end{array}$ & $-22,0000$ & 19,98213 & 5,15937 & $-33,06574$ & $-10,93426$ & $-4,264$ & $14 \quad, 001$ \\
\hline
\end{tabular}

Tabel 5 menjelaskan bahwa nilai sig (2-tailed) adalah 0,001<0,05 yang artinya $H_{a}$ diterima dan $H_{O}$ ditolak, sehingga dapat disimpulkan bahwa perbedaan rata-rata antara hasil belajar sebelum dan sesudah perlakukan kepada peserta didik, yang artinya media sosial WhatsApp dapat meningkatkan keterampilan menulis siswa kelas 7 SMP Generasi Rabbani Bogor.

Berikut hasil perhitungan tingkat efektivitas menggunakan rumus N-Gain:

$$
\begin{gathered}
\mathrm{N}-\text { Gain }=\frac{\text { Skor Postest }- \text { Skor Pretest }}{\text { Skor Maks }- \text { Skor Pretest }} \times 100 \\
\mathrm{~N}-\text { Gain }=\frac{1307,5-925}{100-925} \times 100 \\
\mathrm{~N}-\text { Gain }=57,19 \%
\end{gathered}
$$

Berdasarkan hasil N-Gain diketahui nilai yang didapatkan adalah 57,19\%. Berdasarkan tabel 1 dapat diambil kesimpulan bahwa media sosial WhatsApp terbilang "cukup efektif" dalam meningkatkan keterampilan menulis siswa kelas 7 SMP Generasi Rabbani Bogor.

Hasil dari penelitian dan pembahasan data yang dilakukan oleh peneliti, bahwa pembelajaran daring menggunakan media sosial WhatsApp dapat 
meningkatkan keterampilan menulis. Hal tersebut didukung oleh beberapa penelitian yang telah dilakukan oleh peneliti sebelumnya, seperti penelitian yang telah dilakukan oleh (Umamah \& Muassomah, 2020) membuktikan bahwa pembelajaran daring mampu membentuk siswa untuk aktif, serta membangun kerja sama dalam menyelesaikan tugas-tugas pada materi mahārah kitābah. Selain itu penelitian dari (Widiyanti \& Harunasari, 2019) menunjukkan bahwa pembelajaran menggunakan WhatsApp pada dapat meningkatkan mahārah kitābah siswa ,terutama pada mahārah kitābah dasar karena menurut kebanyakan siswa, kegiatan belajar mengajar dalam menulis teks deskriptif menggunakan WhatsApp membuat mereka lebih termotivasi, menyenangkan dan mudah.

Menurut penelitian yang dilakukan oleh (Larasati, 2013) pemanfaatan aplikasi WhatsApp sebagai sarana dari pembelajaran daring ini dinilai sangat efektif. Ditinjau dari keseluruhan fitur yang dimiliki oleh aplikasi WhatsApp lebih mendukung dibandingkan aplikasi lainnya. Berbagai macam fitur yang dimiliki oleh WhatsApp tersebut yang menambah kemudahan dan kenyamanan berkomunikasi melalui media online (Jumiatmoko, 2016).

Berdasarkan penelitian yang telah dilakukan oleh peneliti sebelumya, pembelajaran menggunakan media WhatsApp ini termasuk efektif. Hal tersebut juga terbukti pada penelitian yang dilakukan di SMP Generasi Rabbani. Pada penelitian ini, WhatsApp tergolong efektif dibuktikan berdasarkan analisis data yang telah dilakukan serta beberapa fitur yang menunjang untuk dijadikan media pembelajaran.

Sedangkan secara teoristis, manfaat fitur WhatsApp yang digunakan dalam pembelajaranmenurut (Prajana, 2017) antara lain:

Yang pertama yakni Chat Group. Fitur ini digunakan untuk menyatukan antara pengajar dan pelajar dalam satu forum di mana mereka dapat berdiskusi dengan bentuk text yang dapat dilihat oleh seluruh peserta grup tersebut. Kemudian fasilitas share dokumen. Fitur ini digunakan untuk membantu pengajar mengirim dokumen dalam bentuk file. Selanjutnya pada fitur kamera. Pada penelitian ini, fitur kamera digunakan untuk memfoto dan Vol. 13, No. 2, Desember 2021 
mengumpulkan hasil tugas yang telah dikerjakan oleh siswa. Lalu pada fitur galeri Fitur ini digunakan untuk membagi atau mengirimkan gambar/video yang telah tersimpan sebelumnya. Dan yang terpenting yakni fitur udio.Penelitian ini menggunakan fitur audio yang digunakan untuk menjelaskan materi dalam bentuk suara. Fitur ini juga sering disebut dengan voice note. Dan yang terakhir yakni fitur YouTube Video Box. Yakni fitur yang dapat digunakan untuk berbagi koleksi video YouTube di WhatsApp.Dari seluruh fitur tersebut, seluruhnya digunakan dalam penelitian di kelas 7 SMP Generasi Rabbani Bogor. Mulai dari chat grup hingga YouTube Video Box.

Agar mengukur keterampilan menulis siswa, diperlukan rumusan indikator yang jelas. indikator keterampilan menulis menurut (Iskandar Wassit 2020):

Pada tingkat pemula terdiri dari Menyalin satuan-satuan bahasa yang sederhana, kemudian dilanjut dengan Menulis satuan bahasa yang sederhana, selanjutnya Menulis pernyataan dan pertanyaan yang sederhana dan yangterakhir yakni Menulis paragraf pendek.Sedangkan untuk tingkat menengah yang terdiri dari Menulis pernyataan dan pertanyaan, kemudian dilanjut dengan Menulis paragraf, selanjutnya Menulis surat, lalu Menulis karangan pendek dan yang terakhir yakni Menulis laporan.

Berdasarkan dari pendapat (Iskandar Wassit 2020) SMP Generasi Rabbani Bogor tergolong pada maharah kitabah di tingkat pemula di poin ketiga, yakni siswa dapat Menulis pernyataan dan pertanyaan sederhana dalam bahasa Arab. Maka penelitian yang telah dilakukan SMP Generasi Rabbani Bogor sudah sesuai dengan indikator maharah kitabah dari(Iskandar Wassit 2020). Karena setelah penggunaan WhatsApp siswa sudah dapat menulis pernyataan dan pertanyaan dengan benar. Hal ini dibuktikan berdasarkan hasil latihan soal yang telah diberikan. Sedangkan sebelum penggunaan WhatsApp, siswa masih belum bisa menuliskan pernyataan dan pertanyaan dengan benar.

Berdasarkan uraian dari tujuan dan target pembelajaran mahārah 
kitābah di atas, dapat direncanakan skenario dari pelaksanaan tahapan pembelajaran mahārah kitābah untuk siswa SMP Generasi Rabbani Bogor:

Berdasarkan beberapa teori dan hasil analisis data yang telah dijelaskan, dapat kita lihat bagaimana hasil belajar peserta didik di kelas 7 SMP Generasi Rabbani Bogor menggunakan media sosial WhatsApp. Dapat diambil kesimpulan bahwa media sosial WhatsAppdapat meningkatkan keterampilan menulis bahasa Arab dengan kategori "cukup efektif". Hal ini dibuktikan dengan uji efektivitas menggunakan rumus N-Gain dengan hasil 57,19\%. Dari tabel 4 kategori tafsiran efektivitas gain, dari (Arini, 2016) didapatkan bahwa 57,19\% tergolong "cukup efektif". Didukung oleh pendapat dari(Widiyanti \& Harunasari, 2019)yang mengatakan bahwa pembelajaran melalui teks deskriptif dengan menggunakan WhatsApp dapat meningkatkan keterampilan menulis siswa.

\section{Kesimpulan dan Saran}

Melalui penerapan media sosial WhatsApp grup, dengan membagikan pretest, kemudian dilanjut dengan membagikan materi pembelajaran berupa video yang dapat diakses melalui youtube. Siswa menyimak dengan baik materi tersebut, peneliti memantau respon siswa selama pembelajaran. Dilanjutkan dengan sesi tanya jawab melalui voice note. Kemudian dilanjutkan dengan mengerjakan posttest. Selama proses pembelajaran, beberapa siswa masih didampingi oleh orangtuanya.

Hasil penelitian menunjukkan terdapat perbedaan signifikan antara nilai pretest dan posttest akhir ditunjukkan dengan rata-rata nilai pretest sebesar 61,66 dan posttest 83,66 . Sedangkan untuk uji efektivitas dibuktikan berdasarkan rumus $\mathrm{N}$-Gain dengan hasil akhir 57,19\%. Artinya media sosial WhatsApp dapat meningkatkan mahārah kitābah di SMP Generasi Rabbani Bogor. Hal ini ditunjukkan berdasarkan nilai pada media sosial WhatsApp untuk meningkatkan keterampilan menulis bahasa Arab yang tergolong "cukup efektif".

Bagi tenaga pendidik, perlu untuk memperhatikan kondisi tingkat 
pemahaman teknologi siswa \& wali siswa selama pembelajaran daring. Sedangkan bagi peneliti selanjutnya, diharapkan mampu memberikan media pembelajaran bahasa Arab yang lebih menarik. 


\section{Daftar Pusaka}

Apriliana, N. M. A. S. (2015). Problematika Pembelajaran Daring Pada Siswa Kelas Iv Mi Bustanul Mubtadin Kecamatan Suruh Kabupaten Semarang (Vol. 9). https://doi.org/http://e-repository.perpus.iainsalatiga.ac.id/id/eprint/9476

Arini, W. (2016). Efektivitas Pembelajaran Kontekstual Praktikum Mata Pelajaran pemrograman Web Siswa Kelas X SMK Muhammadiyah 1 Bantul. Jurnal Pendidikan, 5(5), 1-7.

Asmuni, A. (2020). Problematika Pembelajaran Daring di Masa Pandemi Covid-19 dan Solusi Pemecahannya. Jurnal Paedagogy, 7(4), 281. https://doi.org/10.33394/jp.v7i4.2941

Daheri, M., Juliana, Deriwanto, \& Amda, A. D. (2020). Efektifitas WhatsApp sebagai Media Belajar Daring. Jurnal Basicedu, 3(2), 524-532. https://doi.org/https://doi.org/10.31004/basicedu.v4i4.445

Iskandar, R. (2020). Penggunaan Grup Whatsapp Sebagai Media Pembelajaran Terhadap Peserta Didik Dta At-Tawakal Kota Bandung. Comm-Edu (Community Education Journal), 3(2), 97. https://doi.org/10.22460/commedu.v3i2.3778

Jumiatmoko, M. (2016). Whatsapp Messenger Dalam Tinjauan Manfaat Dan Adab.

Wahana Akademika: Jurnal Studi Islam Dan Sosial, 3(1), 51. https://doi.org/10.21580/wa.v3i1.872

Kuraedah, S. (2015). Aplikasi Maharah Kitabah Dalam Pembelajaran Bahasa Arab $\begin{array}{llll}\text { Sitti Kuraedah. } & \text { Al-Ta'dib, }\end{array}$ https://ejournal.iainkendari.ac.id/index.php/al-tadib/article/view/412/397.

Kurniawan, G. F. (2020). Problematika Pembelajaran Sejarah dengan Sistem Daring. Diakronika, 20(2), 76. https://doi.org/10.24036/diakronika/vol20iss $2 / 148$

Larasati, W. (2013). Efektivitas_Pemanfaatan_Aplikasi_WhatsAp (pp. 5-6). https://doi.org/http://repository.unmuhjember.ac.id/id/eprint/7521

Montolalu, C., \& Langi, Y. (2018). Pengaruh Pelatihan Dasar Komputer dan Teknologi Informasi bagi Guru-Guru dengan Uji-T Berpasangan (Paired $\begin{array}{llll}\text { Sample } & \text { T-Test). } & \text { D'CARTESIAN, } & \text { 7(1), }\end{array}$ Vol. 13, No. 2, Desember 2021 263 
https://doi.org/10.35799/dc.7.1.2018.20113

Mustakim. (2020). Efektivitas Pembelajaran Daring Menggunakan Media Online Selama Pandemi Covid-19 Pada Mata Pelajaran Matematika the Effectiveness of E-Learning Using Online Media During the Covid-19 Pandemic in Mathematics. Al Asma: Journal of Islamic Education, 2(1), 1-12. https://doi.org/https://doi.org/10.24252/asma.v2i1.13646

Rappe. (2021). Shaut Al- ' Arabiyah Pembelajaran Fahmul Masmu ' Bahasa Arab. Shaut Al-'Arabiyah, 9(1), 88-94.

Saifullah, H. (2016). Ayo memahami bahasa Arab VII.

Sugiyono. (2011). Metode_penelitian_kuantitatif_kualitatif_R_ $D_{-}$.

suharsaputra. (2012). metode penelitian kuantitatif, kualitatif dan tindakan.

Tropika, J. E., Magister, P., Biologi, P., Kuala, U. S., Biologi, P. P., Kuala, U. S., Biologi, P. P., \& Kuala, U. S. (2015). Penerapan Model Pembelajaran Problem Based Learning Untuk Meningkatkan Hasil Belajar Siswa Pada Materi Sistem Ekskresi Manusia. Jurnal Edubio Tropika, 3(2), 87-90. 
